\title{
Features of Joint Value Creation in the Context of Digitalization
}

\author{
Elena A. Davydenko \\ Department of Business Economics \\ Saint-Petersburg State University \\ Saint-Petersburg, Russian Federation \\ E-mail: elenadavidenko1@yandex.ru
}

\begin{abstract}
In the context of digitalization, the role of the consumer in value creation is also changing. While companies have previously minimised the involvement of consumers in the creation of products, it is now common for consumers to be involved in the value creation process. At the same time, the process of involvement can be both direct and indirect, for example, through the interaction of consumers with each other and brands in online communities, which gives valuable information to the business for building and adjusting advertising strategies and offering value to customers.
\end{abstract}

Key words: digitalization, digital economy, value, brand, consumer.

The proliferation of sensors and the Internet of Things (IoT) has enabled the creation of digital models based on the vast amount of data collected. These digital models have led to the emergence of new services and business models by connecting multiple devices to high-performance networks, which erases territorial and time constraints to date. The role of the consumer is also changing in the new economic environment. Actual information technologies have led to the fact that the consumer has become active partner for the manufacturer taking part in the process of designing the product or service. The transformation of existing business processes in the digital economy leads to an active dialogue between the producer and the consumer, which leads to a new understanding of joint value creation in the digital economy [1]. Active interaction of consumers in the network leads to the emergence of so-called collective intelligence, which generates such a phenomenon as the effects of social networks, or eWOM (electronic word of mouth). It is worth noting that the effects of social networks have an impact in almost all spheres of activities, where purchases of goods and services are made. At the same time, such effects have the strongest impact in business, based on the impressions of consumers and their personal experience of interaction with the company.

The process of value creation in its traditional sense involves a clear distinction between the roles of the producer and the consumer. The market mechanism allows to move the created value from the producer to the consumer. The value creation process postulates the need to create value together with the consumer, rather than embedding it in the product of the company [2].

It is interesting to see the difference between the terms co-creation of value and co-production. So, P. Chathoth and his co-authors R.J. Harrington, E.S.W. Chan and others [3] show the differences between these terms in a number of criteria. As shown in Table 1, in the framework of joint value creation, the role of the consumer is not limited to advice and opinion expressed by the company, the consumer becomes an equal participant in the value creation process, a participant involved in this process.

Table 1. Comparative analysis of the terms "joint value creation" and "joint production" [3]

\begin{tabular}{|l|l|l|l|}
\hline \multicolumn{4}{|c|}{ Creation" and "joint production" [3] } \\
\hline $\begin{array}{l}\text { The role of the } \\
\text { consumer }\end{array}$ & $\begin{array}{l}\text { Joint value creation } \\
\text { and source of } \\
\text { information }\end{array}$ & $\begin{array}{l}\text { Joint production } \\
\text { resource }\end{array}$ \\
\hline $\begin{array}{l}\text { Consumer } \\
\text { participation }\end{array}$ & $\begin{array}{l}\text { Repeated interactions } \\
\text { at all stages of } \\
\text { creation and } \\
\text { value consumption. } \\
\text { There is a joint } \\
\text { creation of products } \\
\text { and services with the } \\
\text { company. }\end{array}$ & $\begin{array}{l}\text { In the final stages of } \\
\text { the value chain. Adapts } \\
\text { to existing offerings of } \\
\text { the company. }\end{array}$ \\
\hline $\begin{array}{l}\text { Key players in value } \\
\text { creation }\end{array}$ & $\begin{array}{l}\text { Clients, managers } \\
\text { and employees }\end{array}$ & $\begin{array}{l}\text { Managers } \\
\text { employees }\end{array}$ \\
\hline Focus & $\begin{array}{l}\text { Customer focus and } \\
\text { experience of his } \\
\text { participation in the } \\
\text { creation of value }\end{array}$ & $\begin{array}{l}\text { The focus on the } \\
\text { company } \\
\text { production }\end{array}$ \\
\hline $\begin{array}{l}\text { Innovations } \\
\text { Nature of customer }\end{array}$ & $\begin{array}{l}\text { Initiated and } \\
\text { cooperation with the } \\
\text { consumer }\end{array}$ & $\begin{array}{l}\text { Interaction is based } \\
\text { on an open dialogue } \\
\text { with the client. }\end{array}$ & $\begin{array}{l}\text { Representatives of the } \\
\text { company listen to the } \\
\text { opinion of customers. }\end{array}$ \\
\hline
\end{tabular}

To date, R. J. Brodie, L. D. Hollebeek and several others [4] consider the term involving the consumer from the point of view of its participation in virtual communities. Today, digital platforms allow consumers to take an increasingly active part in the activities of virtual communities. And here there are natural questions-why the consumer to participate in such communities? What does he get from this participation? K. P. Gwinner, G. Walsh and others [5] have identified motivations that encourage consumers to participate in these communities through research. 


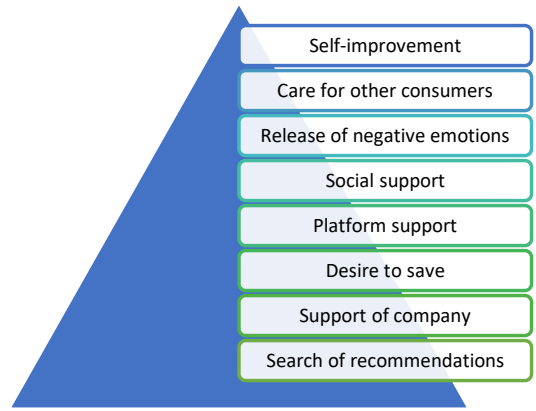

Motivations for consumers to participate in online communities [5]

In turn, the interaction of consumers in online communities with each other and brands is extremely beneficial for companies. What are the advantages of such interactions for business?

- The company can learn more about its active customers. For example, if the demographics of customers in online communities are different from what the ad campaign was originally set up for, the company will need to reconfigure its ad campaign and may even affect how new products are developed or offered.

- The company can understand what content is interesting for its customers. Numerous repost images of the goods indicate that the company has attracted the attention of consumers. The more attention a company gets, the more brand awareness spreads.

- Increased site traffic. Interaction in social networks is a way to organically increase the flow of traffic. The increase in activity in social networks, whether "likes", reposts or comments, gives an increase in visits to the business site. Well, every new visit is another chance for conversion.

- Strengthening ties with the customer base. Social media advertising enables the company to reach out to consumers in a way that doesn't make them feel pressured. You can use social media to answer consumer questions, solve problems, and even make consumers feel special by making them special offers.

- Using online communities, you can perfect your brand identity and gain the trust of your customers. Trust and branding are two strongly intertwined factors. Online presence helps the brand to communicate its values and views that may well resonate with customers. Many consumers argue that "shared values" are the main reason for their brand loyalty.

Social media encourages customers to provide marketing materials for the company. Creative consumers use their pages on social networks and online communities to publish information about the products they use, the places they visit, the companies that mean something to them. Thus, companies receive virtually free advertising. Social media allows you to communicate with customers directly-and allow them to communicate with the company.

At the same time, today many companies focus exclusively on getting subscribers and clicks. Instead, a more effective strategy is to coordinate a PPC (pay per click) campaign with social media marketing. Cross-channel events allow you to fine-tune your PPC campaign with all the information that social networks provide. Companies can adapt their PPC strategy to deliver optimized ads directly to customers who are likely to convert.

In turn, paid clicks can actually lead to the creation of custom content, which ultimately will lead to an organic increase in site rankings in search engines. If a customer clicks on an ad, and then places a link to the site or talks about a product on his page, he raises the company's rating in the search results.For example, on Facebook, the custom audiences feature can only be used to promote your ad to users who show the most organic engagement. In Google AdWords, you can use the "customer email Targeting" feature for the same purpose.

Thus, the following conclusions can be drawn:

- The transformation of existing business processes in the digital economy leads to an active dialogue between the producer and the consumer, which leads to a new understanding of joint value creation in the digital economy.

- Digital platforms allow consumers to become increasingly involved in virtual communities.

- Among the motives that encourage consumers to participate in virtual communities, we can call such motives as finding recommendations, social support, care for other consumers, support for the company, selfimprovement.

- Interaction of consumers in online communities with each other and with the brand turns out to be beneficial for business, allowing organizations to optimize their advertising campaigns for the actual needs and interests of the target audience.

\section{REFERENCES}

[1] Трачук А.В., Линдер Н.В. Трансформация бизнес-моделей электронного бизнеса в условиях нестабильной внешней среды // Эффективное антикризисное управление. 2015. № 2. C. 58-71. [Trachuk A. V., Linder N. V. Transformation of business models of electronic business in conditions of unstable external environment // Effective Crisis Management. 2015. № 2. P. 58-71].

[2] Lusch R.F., Vargo S.L. Service-dominant logic: reactions, reflections and refinements // Journal of Marketing Theory. 2006. № 6 (3). P. 281-288.

[3] Chathoth P., Altinay L., Harrington R.J. et al. Co-production versus co-creation: A process based continuum in the hotel service context // International Journal of Hospitality Management. 2013. № 32. P. 11-20.

[4] Brodie, R.J., Hollebeek L.D., Ilic A. et al. Consumer engagement in a virtual brand community: An exploratory analysis // Journal of Business Research. 2011. № 66(1). P. 105-114.

[5] Hennig-Thurau T., Gwinner K.P., Walsh G. et al. Electronic word-of-mouth via consumer-opinion platforms: What motivates consumers to articulate themselves on the Internet? // Journal of Interactive Marketing. 2004. № 18 (1). P. 38-52. 